\title{
Contar, Rememorar e Cuidar: Lembranças Sobre a Comida e o Comer de um Grupo de Idosos em Santos
}

\author{
Frutuoso, Maria Fernanda Petroli; Severo, Amanda Beatriz Almeida; \\ Tavares, Cremilde Martins \\ Universidade Federal de São Paulo Campus Baixada Santista — fernanda.frutuoso@unifesp.br
}

Introdução: a complexidade das práticas alimentares contemporâneas e suas interfaces com o processo de saúde-adoecimento-cuidado colaboram para um hiato entre discurso e práticas profissionais que envolvem a comida e o comer na medida em que as condutas hegemônicas apresentam enfoque predominantemente biológico, muitas vezes, reduzido à orientação de mudança de hábitos alimentares definidas a partir da relação da dieta com o risco de adoecimento e morte, distante de fatores culturais e sociais de indivíduos, famílias e grupos. Este contexto traz peculiaridades para a abordagem nutricional em idosos diante do processo de envelhecimento e seus impactos biológicos e sociais, entre outros. Diante da atual discussão sobre a humanização em saúde mostra-se necessário investir na reflexão sobre práticas que favoreçam o estabelecimento de vínculo ente os vários atores implicados no processo de cuidado em saúde, aperfeiçoando a gestão compartilhada e aumentando o poder do sujeito que adoece e da população. Objetivo: Este trabalho teve como objetivo conhecer as memórias alimentares de um grupo de idosas residentes em uma região de elevada vulnerabilidade em Santos, São Paulo. Metodologia: Foi realizada pesquisa qualitativa com idosas moradoras de uma região periférica de Santos, SP. a coleta de dados ocorreu em oficinas culinárias, que incluíam as receitas mais citadas pelas participantes como parte da memória alimentar, seguidas de grupos focais que visou a conhecer as sensações experimentadas e as lembranças desencadeadas durante o cozinhar e o comer junto. Resultados: As receitas mais marcantes foram feijão fradinho com carne seca, cuscuz baiano salgado, bolo de mandioca e tapioca. a análise sistemática das narrativas mostrou que o cozinhar e o comer estão intimamente relacionados à identidade, ao gosto e ao grupo social ao qual as idosas pertencem. As falas evidenciaram uma forma peculiar de produzir, preparar e consumir os alimentos, indicando disponibilidade de tempo para estas ações. As mulheres referiram que as oficinas constituíram espaço de escuta e troca de conhecimentos, valorizando o saber popular. Conclusão: a memória alimentar do grupo aponta para o importante papel feminino na culinária; para a grande influência da identidade nas escolhas alimentares e para a comida, o cozinhar e o comer serem meios para contar histórias e ressignificar momentos. As oficinas culinárias e a criação de espaços que permitam o diálogo sobre a comida e o comer, de forma a valorizar o saber popular, a memória e o gosto alimentar, foram estratégias de aproximação dos participantes, permitindo uma escuta sensível, sobre a história de vida, vivências e demandas do grupo, favorecendo a elaboração e execução de práticas menos culpabilizadoras e mais acolhedoras e co-produzidas, que entendam a comida, o cozinhar e o comer como narrativa que transmita memória e cultura.

Frutuoso, Maria Fernanda Petroli; Severo, Amanda Beatriz Almeida; Tavares, Cremilde Martins. Contar, Rememorar e Cuidar: Lembranças Sobre a Comida e o Comer de um Grupo de Idosos em Santos. In: Anais do Congresso

Internacional de Humanidades \& Humanização em Saúde [= Blucher Medical Proceedings, num.2, vol.1]. São Paulo: Editora Blucher, 2014. ISSN 2357-7282

DOI 10.5151/medpro-cihhs-10726 